\title{
20. MILANKOVITCH CYCLES FROM FOURIER ANALYSIS OF LOGS FROM SITES 865 AND $866^{1}$
}

\author{
Patricia Cooper ${ }^{2}$
}

\begin{abstract}
Ocean Drilling Program (ODP) Sites 865 and 866, at Allison and Resolution guyots, respectively, were logged during Leg 143. Shipboard analysis of recovered core materials indicated rhythmic repetition of shallowing-upwards facies, however, recovery at both sites averaged less than $16 \%(1 \%-2 \%$ in the shallow-water limestones). The original depth of the recovered core material was not known with certainty, which precluded visual quantification of Milankovitch cycles. The geophysical logs, which provided continuous records of lithologic changes, were analyzed in an attempt to detect Milankovitch periodicities.

Age controls were not sufficient to provide time constraints for the logged interval from 102.5 to $867.0 \mathrm{mbsf}$ of Site 865 ; however, the entire depth interval is of late Albian age. Logs exhibit strong cyclicity in the depth interval from 250 to 490 mbsf that is mainly controlled by variations in porosity and, to a lesser extent, clay content. Sedimentation rate increases slightly downhole. Because of the high, although variable, accumulation rate (about two times the Albian sedimentation rate at Resolution Guyot), the spectral analysis revealed high-amplitude frequencies corresponding to eccentricity and obliquity. The cycle frequency corresponding to a Milankovitch period of $413 \mathrm{k} . \mathrm{y}$. dominates all spectra; the frequency corresponding to $123-95 \mathrm{k} . \mathrm{y}$. has high-amplitude for the interval from 330 to $490 \mathrm{mbsf}$. Vertical resolution was not high enough to resolve frequencies corresponding to precession.

At Site 866, the logged interval, from 78.0 to $1679.4 \mathrm{mbsf}$, corresponds to a time interval of about $33 \mathrm{~m} . \mathrm{y}$. Two depth intervals showed strong cyclicity in the geophysical logs: $430-670$ and $935-1135 \mathrm{mbsf}$. Sedimentation rate is highly variable and increases downhole from about $30 \mathrm{~m} / \mathrm{m}$.y. in the middle-to-late Albian section to about $80 \mathrm{~m} / \mathrm{m} . \mathrm{y}$. in the Barremian section. Vertical resolution was not sufficient to resolve frequencies corresponding to precession; the $41-\mathrm{k}$.y. obliquity peaks are resolvable only in the lower portion of Hole 866A. The 413-k.y. eccentricity cycle dominates all spectra. The 123- to 95-k.y. cycles, which are probably the alternations between wackestone and more coarse-grained packstones, likely represent the combined influence of obliquity and eccentricity orbital perturbations on sea level.
\end{abstract}

\section{MILANKOVITCH CYCLES IN SEDIMENTS}

Since 1976 (Hays et al., 1976), analyses of time series of climatesensitive indicators have provided geological evidence that a major portion of climate variation is driven by changes in insolation caused by perturbations in Earth's orbital parameters. Such quasi-periodic climate variations were predicted originally by Milankovitch (1941). Exactly how changes in the insolation patterns are translated into climatic changes remains the subject of extensive research. Nevertheless, the periods of orbital eccentricity (413 and 123-95 k.y.), obliquity (41 k.y.), and precession (23-19 k.y.) have been observed in analyses of a variety of sediment types and in many stratigraphic intervals.

Percentage of calcium carbonate content and oxygen isotope ratios (e.g., Briskin and Harrell, 1980) are parameters frequently used for detecting Milankovitch frequencies in Quaternary pelagic sediments. Oxygen isotope ratios for benthonic marine foraminifers, as well, reflect global ice volume; numerous published studies clearly demonstrate that Quaternary glacial regimes are related to orbital periodicities (Imbrie et al., 1984). Because the magnitude of the change in insolation caused by the precession-obliquity-eccentricity cycles is so small (Berger, 1977), models that seek to explain climate cycles in terms of variations in insolation include climatic-oceanic feedback mechanisms that amplify the magnitude of the resultant climate changes (Berger et al., 1984; Sundquist and Broecker, 1985; Barron et al., 1985; Prell and Kutzbach, 1987; Sarnthein et al., 1988). In particular, most theoretical studies to date have placed great emphasis on ice-sheet amplification of the relatively weak Milankovitch signals (Berger et al., 1984; Start and Prell, 1984; Ruddiman and McIntyre, 1984).

Confirmation of the effects of climatic forcing in sediments of pre-Quaternary age extends over a range of sedimentary systems,

\footnotetext{
' Sager, W.W., Winterer, E.L., Firth, J.V., and Sinton. J.M. (Eds.), 1995. Proc. ODP, Sci. Results, 143: College Station, TX (Ocean Drilling Program).

${ }^{2}$ Department of Geology and Geophysics, University of Hawaii, 2525 Correa Rd., Honolulu. HI 96822, U.S.A.
}

both siliciclastic and carbonate, and depositional environments. For example, mean periodicities of 20,40 , and 100 k.y. have been derived for carbonate-marl deposition in the Cretaceous and lower Tertiary of the Apennines (e.g., Arthur and Fischer, 1977), for pelagic sediments drilled in the open ocean (e.g., Dean et al., 1977; Arthur, 1979; McCave, 1979), for Triassic shallow marine carbonates in the northern Alps (e.g., Schwarzacher, 1964; Fischer, 1964), and for Eocene (Bradley, 1929) and Triassic lacustrine sediments (e.g., van Houten, 1964; Olsen et al., 1978) in the U.S. Parameters most useful in the study of these sediment types include variations in porosity or grain size, the relative abundance and mineralogy of clays, and variations in one or more of the biogenous components. Previous studies of geologic time series from Cretaceous deep-ocean sediments (e.g., McCave, 1979; Arthur, et al., 1984; Cotillon and Rio, 1984; de Graciansky and Gillot, 1985; Herbert and Fischer, 1986) revealed the same, or similar, high power in the eccentricity and precession peaks, regardless of the ocean of origin, indicating that this is truly a global signature that persists through geologic time.

Although the volume of polar ice caps during the Cretaceous is not known accurately (Kemper, 1987), Hardie et al. (1986) suggest that the growth patterns of ice caps with even greatly reduced volume would cause eustatic fluctuations on the order of several meters, sufficient to cause emergence cycles at carbonate platforms. The persistence of Milankovitch periodicities through the Cretaceous, a time of warm seas and possibly minimal ice cover (Barron and Washington, 1985), implies that, whereas the presence of ice sheets may be an important factor in the modulation of global climate, their presence is not required for such modulation to occur (Fisher et al., 1985; Herbert et al., 1986).

Jarrard and Arthur (1989) first explored the feasibility of using spectral analysis of downhole geophysical logs to detect cyclic changes in mineralogy and porosity in Pleistocene sediments from Sites 645 in the Labrador Sea and 646 in Baffin Bay. Their analysis revealed periodicities of roughly 20,40 , and $100 \mathrm{k} . \mathrm{y}$. in the sonic, resistivity and U/Th logs. They reasoned that fluctuations in bottomwater currents in response to Milankovitch cycles caused the ob- 
served variations in clay content and porosity. Amplitude spectra of gamma-ray, sonic, and resistivity logs in upper Tertiary sediments at Site 693 on the Antarctic continental margin yielded obliquity and eccentricity cycles (Golovchenko et al., 1990). Obliquity and possibly eccentricity cycles also were observed in amplitude spectra of calcium and silica from Site 704 on Meteor Rise (Mwenifumbo and Blangy, 1991; Nobes et al., 1991). The results of an analysis of the natural gamma-ray log from Site 798 on the Oki Ridge suggested obliquity modulation of the Pliocene-Pleistocene eolian dust influx to the Sea of Japan (DeMenocal et al., 1992). Molinie and Ogg (1992) reported cycles of variable concentrations of radiolarians and clay and degree of silicification in upper Middle Jurassic to Lower Cretaceous radiolarites from spectral analysis of gamma-ray logs from Site 801 . They used the wavelength of the eccentricity-modulated signals to determine sedimentation rates. Glenn et al. (1993) investigated the translation of climate modulation by Milankovitch-like forcing into sedimentary cycles in mixed carbonate and siliciclastic sediments using sonic logs from Site 821 off of the Great Barrier Reef, Australia. Climate modulation at that site incorporates such factors as lags in ocean-climate response to orbitally produced changes in insolation, as well as independent changes in sediment supply (e.g., turbidites) and tectonic subsidence.

\section{ODP SITE SETTINGS}

This study uses two sets of geophysical logs obtained during Leg 143 at Allison and Resolution guyots, Sites 865 and 866, respectively. Deep holes were drilled into the Cretaceous lagoonal facies of Allison and Resolution guyots to address fundamental problems concerning guyot development (Sager, Winterer, Firth, et al., 1993).

Hole 865A (Fig. 1), atop Allison Guyot in the central Mid-Pacific Mountains, was drilled between the summit of the pelagic cap and the south rim of the guyot. The hole penetrated $870.9 \mathrm{mbsf}$, through $140 \mathrm{~m}$ of pelagic cap and $698 \mathrm{~m}$ of late Albian shallow-water limestone, and bottomed in $33 \mathrm{~m}$ of basaltic sills intruded into limestone. Facies imply clay-, organic-, and pyrite-rich marsh settings in the lower part of the hole and restricted-lagoonal environments in the upper part (Shipboard Scientific Party, 1993a). Hole 866A (Fig. 1), atop Resolution Guyot, $716 \mathrm{~km}$ to the northwest of Site 865 in the Mid-Pacific Mountains, was located about $1 \mathrm{~km}$ inboard from the edge of the summit within a trough behind the perimeter mound. The hole penetrated $1743.6 \mathrm{mbsf}$, through $25 \mathrm{~m}$ of pelagic sediments and $1620 \mathrm{~m}$ of Albian to Hauterivian shallow-water limestones overlying about $124 \mathrm{~m}$ of basalt. Dolomitized oolitic and oncolitic grainstones that cover the volcanic basement give way at 1400 mbsf to peritidal facies that contain scattered coral and rudist reefs and beach sediments. The upper part of the platform (from about $680 \mathrm{mbsf}$ ) comprises lagoonal carbonates with scattered calcrete horizons (Shipboard Scientific Party, 1993b).

Although average recovery was very low $(15.1 \%$ for Hole $865 \mathrm{~A}$, $15.4 \%$ for Hole $866 \mathrm{~A}$ ), the cored material from both holes clearly showed that the sedimentary record was composed of multimeterscale sequences. In the upper part of Hole 866A (430-670 mbsf), the sequences were particularly well developed in the lagoonal facies; recurring meter-scale cycles typically began as laminated organicrich mudstones and graded upward into bioturbated, less organic-rich packstones and grainstones, and then into wackestone with moldic porosity. Facies from the lower part of Hole 866A (935-1165 mbsf) implied cyclic changes of the depositional environment from subtidal to intertidal-supratidal and returning to subtidal. Desiccation cracks and a calcified algal mat at the base of a typical sequence indicated emergence of the platform during low relative sea level. The subsequent rise in relative sea level resulted in reworking of the mudstone and algal mat as a flat-pebble conglomerate followed by deposition of a shallowing-upward facies as the carbonate accumulation rate outpaced the relative rise in sea level. Many sequences are incomplete. Similar multimeter-scale peritidal sequences were identified by James (1977) and Shinn (1983) in both ancient and recent carbonate deposits. Grotzinger (1986), Hardie et al. (1986), and Strasser (1991) ascribed such sequences to sea-level fluctuations related to climatic forcing as described by Milankovitch (1941).

Laboratory analyses of core samples from Hole 866A revealed that the distribution of $\mathrm{MnO}, \mathrm{Zn}$, and $\mathrm{Cu}$ (Röhl et al., this volume) displayed much longer cycles ( 50 to $100 \mathrm{~m}$ ) in the interval from 680 to $1400 \mathrm{mbsf}$ which were thought to correlate to packets of cycles seen in the lithology. Although these geochemical cycles are based on from four to six samples, the trends are clear, and additional samples would not change the cycle lengths significantly.

A strong cyclicity was noted in the downhole log responses for Hole 865A from 250 to $490 \mathrm{mbsf}$ (Fig. 2) and for Hole 866A from 430 to 664 and from 935 to $1165 \mathrm{mbsf}$ (Fig. 3). Further, the portions of the geophysical logs displaying this cyclical character at both Allison and Resolution guyots corresponded almost exactly to cored intervals displaying cyclic variations in lithologies. The high degree of correlation between the sonic and resistivity logs (Fig. 4) suggested that porosity variations were the dominant effect; however, porosity variations in cores are difficult to recognize visually.

Spectral analysis of the resistivity and gamma-ray logs from Sites 865 and 866 and the sonic $\log$ from Site 865 was undertaken (1) to investigate a possible relationship between the observed sedimentary rhythms and climatic forcing and (2) to determine possible causes.

\section{DATA}

A standard suite of logging runs was made at Hole $865 \mathrm{~A}$ within the open borehole between 100.5 and 867.0 mbsf. In Hole 866A at Resolution Guyot, logging covered the interval from 74.5 to $1679.4 \mathrm{mbsf}$ or less (at Hole $866 \mathrm{~A}$ the bottom of the hole was not logged because of cave-ins at or above 1680 mbsf; Sager, Winterer, Firth, et al., 1993). The sonic, medium-induction resistivity, and natural gamma-ray logs from both holes were used in this study. Formation velocity was calculated by taking the inverse of the sonic log and depends upon both lithology and porosity and the resistivity log responds primarily to porosity variations. The gamma-ray $\log$ measures the natural radioactivity of the formation and provides a qualitative evaluation of the clay or shale content because radioactive elements tend to be concentrated in the lattice structures of clay minerals. At both holes, cycle skipping and other noise caused by lack of centering of the tool compromised the quality of the sonic logs. The sonic log for Hole 866A was not used at all owing to this problem; although, the reprocessed sonic $\log$ for Hole $865 \mathrm{~A}$ was used for the 410- to 490-m interval because no resistivity data were available for that interval.

As mentioned previously, a visual inspection of the geophysical logs suggested a correlation with the shipboard sedimentological and geochemical observations of short- $(1-10 \mathrm{~m})$ and long-wavelength (50-100 m) variations in carbonate facies. Data segments were chosen for spectral analysis (1) to coincide with the intervals of cyclic sedimentation identified in the cores, (2) to avoid major sedimentary lacunae (e.g., at the Hole 866A lithologic Unit V/Unit VI boundary, $791.8 \mathrm{mbsf}$ ), and (3) to avoid major diagenetic horizons, such as the phosphatization in the upper sediments at Hole $865 \mathrm{~A}$ and the dolomitization in the lower portion of Hole 866A.

A major limitation for using the downhole logging data is one of vertical resolution (Jarrard and Arthur, 1989; deMenocal et al., 1992); that is, the resolution and sampling interval of the tool, combined with a particular sedimentation rate, determines the minimum detectable cycle. For example, a resistivity-log having a $1-\mathrm{m}$ vertical resolution (Schlumberger, 1987) requires a minimum sedimentation rate of 20 $\mathrm{m} / \mathrm{m}$.y. to detect the eccentricity signals $(95,123$, and $413 \mathrm{k} . \mathrm{y}$.) because Fourier analysis requires at least two points per cycle; similarly, a sedimentation rate of $100 \mathrm{~m} / \mathrm{m}$.y. is required to detect precessional signals ( 23 and 19 k.y.). The sedimentation rate and vertical tool resolution combine to act as a high-cut filter. The natural gamma-ray intensity logging tool has a resolution of $0.3 \mathrm{~m}$ and the sonic $\log$ has a resolution of $0.6 \mathrm{~m}$ (Schlumberger, 1987). Slight spectral contami- 


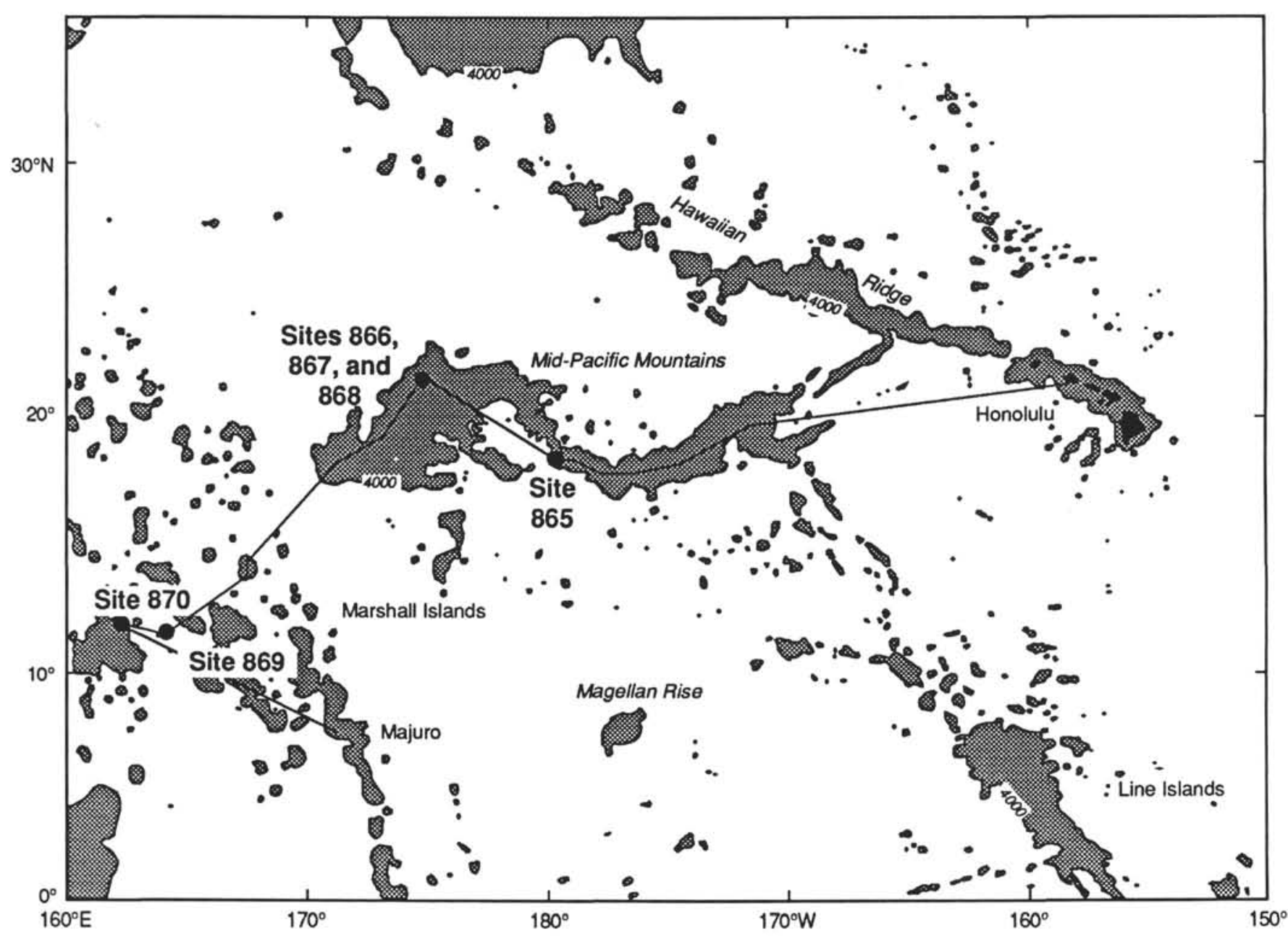

Figure 1. The region visited by JOIDES Resolution during Leg 143. Seafloor shallower than $4 \mathrm{~km}$ is stippled. The locations of Leg 143 drill sites and ship's track are shown.

nation may exist near the Nyquist frequency because the sampling interval $(0.15 \mathrm{~m})$ is smaller than the vertical resolution of the logs, however, that is not within the frequency band of interest here. Although the gamma-ray spectra possess more power at higher frequencies, the gamma-ray tool also is affected by residual noise that degrades the low-frequency resolution (deMenocal et al., 1992).

Whereas the response of the depositional environment to astronomical climate forcing is periodic in time, the data recorded by the logging tool is periodic in depth. As long as the sediment accumulation rate is constant over long time periods, then the cyclic variation of physical properties with depth (depth series) will approximate a variation with time (time series). Spectral analysis of a depth series at constant accumulation rate yields temporal cycle frequencies as measured in cycles/meter. The spatial wavelength of the cycles must be constant for the entire depth section or resolution may be degraded as the peaks seen in the amplitude spectra are increasingly smeared at high frequencies by slight variations in sedimentation rate (e.g., deMenocal et al., 1992; Mayer et al., 1993).

\section{METHODS}

Sequentially sampled discrete data, whether digital waveforms or downhole logs, possess three basic components: a trend, a periodic (signal), and random (noise) components. Trends may be detected visually in the logging data as linear increases in velocity or resistivity with depth due to compaction. A linear regression analysis was performed to detect the presence of and to remove trends (i.e., deviations of the dependent variable, resistivity, velocity, or gamma, from a straight line fitted to the data are minimized). Aunique line thereby can be defined about which variance is a minimum. If the values along this line are subtracted from the corresponding data points, the resulting data set has a mean of zero; removing the trend removes the zero-order term that would otherwise dominate the spectrum (Schickendanz and Bowen, 1977). The data set then was standardized by dividing by the standard deviation. Standardization ensures numerical stability in calculations and reduces the calculated amplitudes to percent of total variance.

The windowing process acts as a low-cut filter in that it removes long-period cycles. High-frequency noise in the natural gamma-ray logs was not a serious problem; hence, all spectra were calculated using unfiltered logs.

Complex waveforms are constructed by the addition of successive harmonics, and the relative importance of a particular harmonic is a function of its amplitude, which will be zero if the harmonic is not present. The purpose of Fourier analysis is to extract the dominant harmonic components. In a finite data sequence of $N$ equally spaced points, $N / 2$ harmonics can be computed. By choosing a data segment length (e.g., 525 samples or $80 \mathrm{~m}$ for Hole 865A) the fundamental wavelength is arbitrarily set. Successive harmonics are computed in terms of this length (e.g., cycles per $80 \mathrm{~m}$ for Hole 865A; Fig. 5). Because the windowing process can introduce spurious peaks ("sidelobes") into the spectrum, a Hanning filter (Jenkins and Watts, 1968) was applied to smooth each spectrum. Smoothing tends to reduce amplitudes slightly and to merge nearby maxima. 


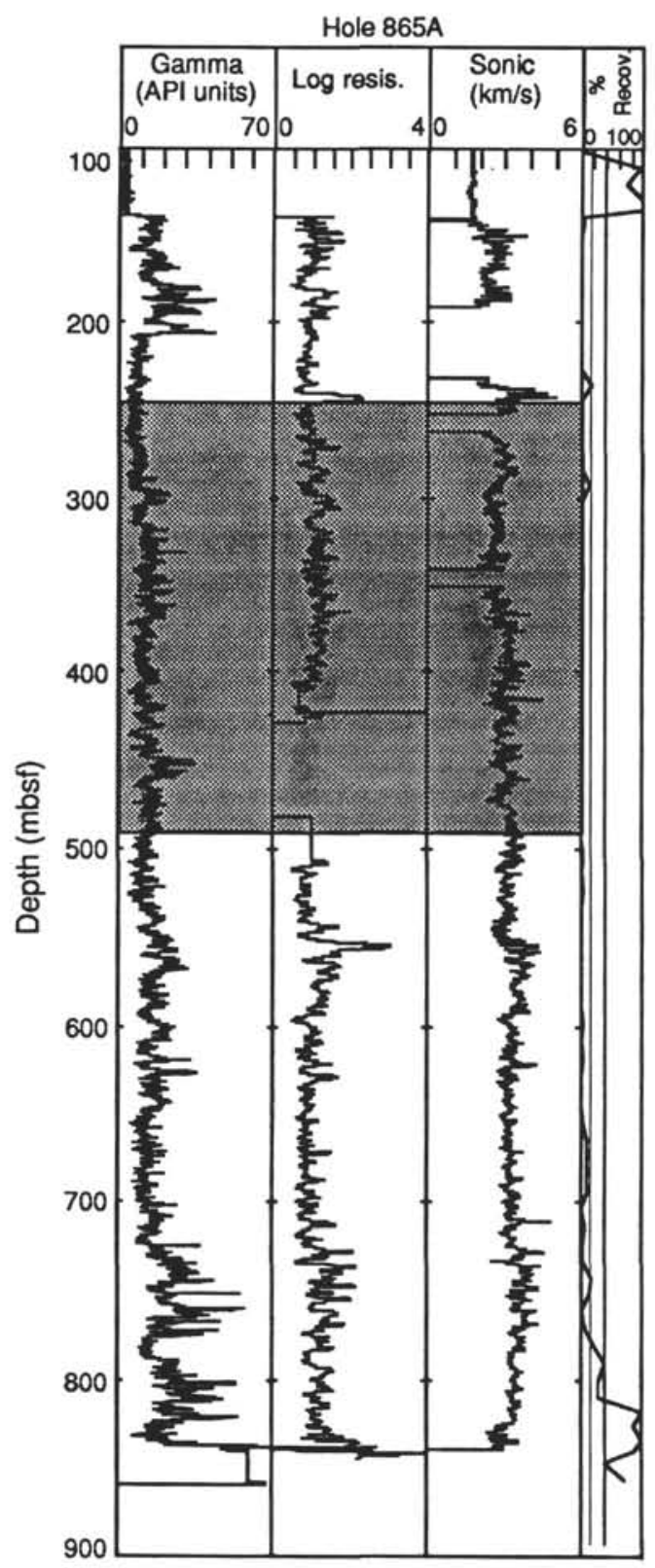

Figure 2. Gamma-ray, resistivity, and sonic logs for Hole 865A. Fourier analysis was performed on the stippled portions of the data. The resistivity and sonic logs suffered data losses from mechanical failure and noise contamination, respectively. Resistivity log scale is logarithmic.

Two methods are commonly used to demonstrate that spectral peaks are equivalent to Milankovitch orbital periodicities. Preferably, sedimentation rates that are obtained independently using biostratigraphic data may be used to estimate the frequencies of the sediment cycles. Alternatively, one may compare the ratios of the frequencies of the spectral maxima to the ratios of Milankovitch time periodicities (e.g., Park and Herbert, 1987). No sedimentation rates have been calculated for the Albian section of Hole $865 \mathrm{~A}$ because no definitive zonal boundaries could be defined. At Hole $866 \mathrm{~A}$, biostratigraphic (Sliter et al., this volume) and isotope data (Jenkyns, this volume) combine to produce the following age controls that were used to estimate accumulation rates: Albian/Aptian boundary at $500 \mathrm{mbsf}$ (112 Ma); Aptian/Barremian boundary at $900 \mathrm{mbsf}$ (125 Ma); and Barremian/Hauterivian boundary at $1500 \mathrm{~m}$ (132 Ma); the geologic time scale used is that of Harland et al. (1990). For Figures 6 and 7 depths were converted to ages using a linear interpolation between the ages at these boundaries.

Because sedimentation rates were unknown for Site 865 and little known for Site 866 , amplitude spectra for the resistivity and gamma logs were computed first for 200-m data windows and then the window size was gradually reduced. It was assumed that the sedimentation rate was constant throughout each window. The ratios of the peak frequencies contained within these long data windows were consistent with those of the Milankovitch eccentricity (413/123 k.y. and 413/95 k.y., 3.3 and 4.3) and obliquity period (413/41 k.y., 10.1). Assuming correct identification of the Milankovitch periods present in the data, a sedimentation rate then was estimated from their spatial wavelengths. Figure 8 shows a portion of such an exercise for Hole 865A: the ratios of the dominant eccentricity peaks are similar for window lengths that ranged in length from 78 to $122 \mathrm{~m}$. Based on the observed spatial wavelengths, the average sedimentation rate at Hole $865 \mathrm{~A}$ was about $65 \mathrm{~m} /$ m.y. ( 250 to $490 \mathrm{mbsf}$ ). A window length of $80 \mathrm{~m}$ was used for all further calculations for Hole $865 \mathrm{~A}$. Average sedimentation rates for Hole $866 \mathrm{~A}$ estimated from observed spatial wavelengths were 37 $\mathrm{m} / \mathrm{m}$.y. (431 to $664 \mathrm{mbsf}$ ) and $75 \mathrm{~m} / \mathrm{m}$.y. ( 935 to $1165 \mathrm{mbsf}$ ), which compared favorably to sedimentation rates calculated from a linear interpolation between age horizons: $33 \mathrm{~m} / \mathrm{m} . \mathrm{y}$. and $77 \mathrm{~m} / \mathrm{m} . \mathrm{y}$. Amplitude spectra of the natural gamma-ray, sonic, and resistivity logs were calculated for Hole 866A using depth windows of $33 \mathrm{~m}$ (Fig. 6) and $77 \mathrm{~m}$ (Fig. 7), each equivalent to 1 million years.

\section{RESULTS}

\section{Hole 865A}

Amplitude spectra for three depth windows of the gamma-ray and resistivity logs (top two panels) and gamma-ray and velocity logs (bottom panel) from Hole 865 A are shown in Figure 5. These logs show similar frequency contents in all windows, although the relative positions and magnitudes of maxima change with depth. Most of the variance is in frequencies of less than 30 cycles per $80 \mathrm{~m}$, therefore, the amplitude spectrum is truncated at 80 cycles per $80 \mathrm{~m}$ with no loss of data.

For comparison with the observed frequencies, predicted locations of Milankovitch frequencies were calculated from the relationship (Golovchenko et al., 1990):

Predicted frequency $=$ [window length $(\mathrm{m}) /$ sedimentation rate (m/m.y.)]/orbital period (m.y./cycle).

The solid vertical lines in Figure 5 indicate the predicted positions of (from left to right) the 413-, 123-, 95-, and 41-k.y. Milankovitch frequencies for a sedimentation rate of $65 \mathrm{~m} / \mathrm{m}$.y. In most spectra, the highest amplitude peaks correspond to the predicted peak frequencies for eccentricity, 413, 123, and 95 k.y. It is apparent that this sedimentation rate, derived from a reconnaissance spectral analysis of a 200-m data window, is approximately correct only for the top interval (250-330 mbsf). The 123- and 95-k.y. peaks are merged. Gamma-ray log spectra show a trend toward increasing energy with depth in the 95-123 band. In the interval from 330 to $410 \mathrm{mbsf}$, a spectral peak lies near the 41-k.y. obliquity frequency, about 30 cycles per $80 \mathrm{~m}$. Such a frequency is well within the resolution of both gamma-ray and resistivity logs at this sedimentation rate. Its absence from the interval 250-330 and low amplitude in the interval 410-490 implies that either sedimentary processes, such as erosion and redeposition or diagenesis, are acting to obliterate the signal by causing the apparent sedimentation rate to vary enough within the depth interval to smear the high-frequency signal.

If we assume that the spectral peaks represent the true periodicities of the orbital parameters, then slight errors in the assumption of constant sedimentation rate are evident as shifts in the positions of observed peaks with respect to predicted peaks within a spectrum. For 

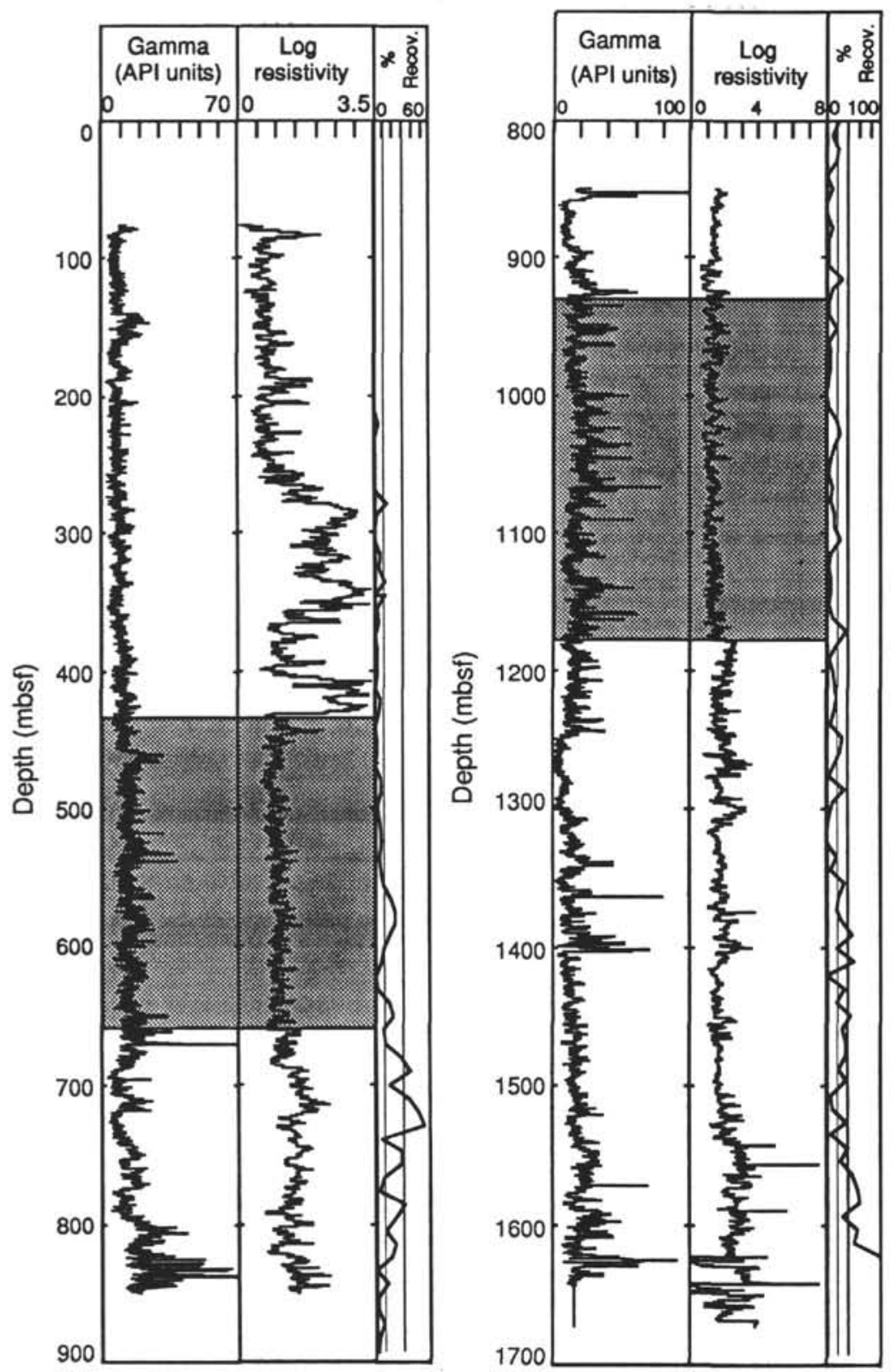

Figure 3. Gamma-ray and resistivity logs for Hole 866A. Fourier analysis was performed on the stippled portions of the log. Resistivity log scale is logarithmic. the interval from 250 to 330 mbsf, observed peaks are shifted slightly to the right of the predicted peaks, suggesting that the sedimentation rate is less than $65 \mathrm{~m} / \mathrm{m}$.y. Similarly, peaks in the intervals from 330 to 410 and from 410 to 490 mbsf have shifted to the left, suggesting that the sedimentation rate is greater than $65 \mathrm{~m} / \mathrm{m}$.y.

\section{Upper Portion of Hole 866A}

Resistivity and gamma-ray logs for Hole $866 \mathrm{~A}$ are displayed in Figures 6 and 7 at a vertical depth scale that corresponds to the summed lengths of the windows. The sonic log at this site is of such poor quality that it was not used for this site. Vertical lines on the figure indicate the predicted frequencies of Milankovitch periodicities for an average sedimentation rate of $33 \mathrm{~m} / \mathrm{m}$.y. The 413-k.y. peak dominates the spectra of all depth intervals.

A strong cyclicity is evident in the logs, although the frequency content varies with depth and much longer-period variations occur in the upper $33 \mathrm{~m}$ ( 431 to $464 \mathrm{mbsf}$ ) than in the sections below that level. Little energy is present in that spectrum at frequencies greater than about 15 cycles/m.y; further, the gamma-ray (dotted-line spectrum)

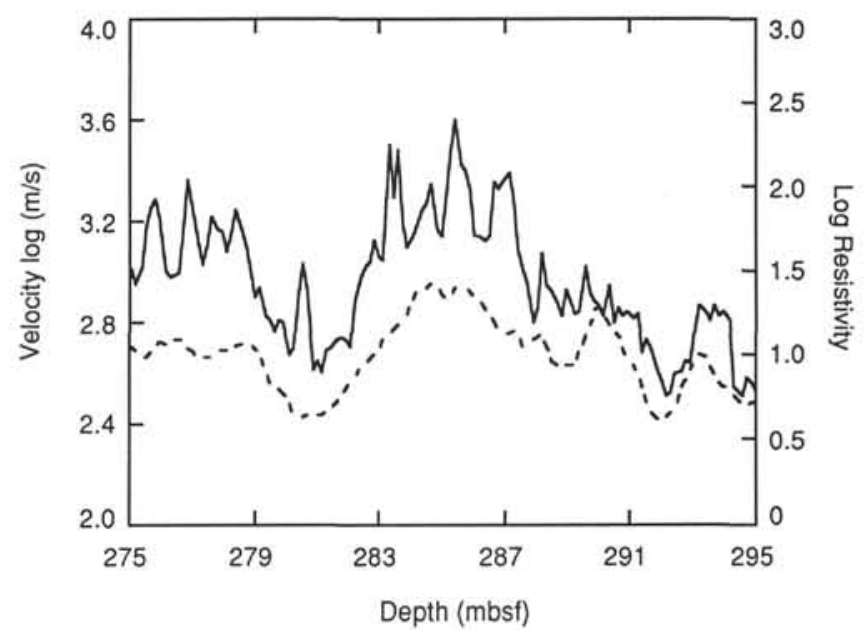

Figure 4. Expanded plot of the resistivity and sonic logs for a portion of Hole $865 \mathrm{~A}$, illustrating the close correspondence between the two porosity logs. Resistivity log scale is logarithmic. 


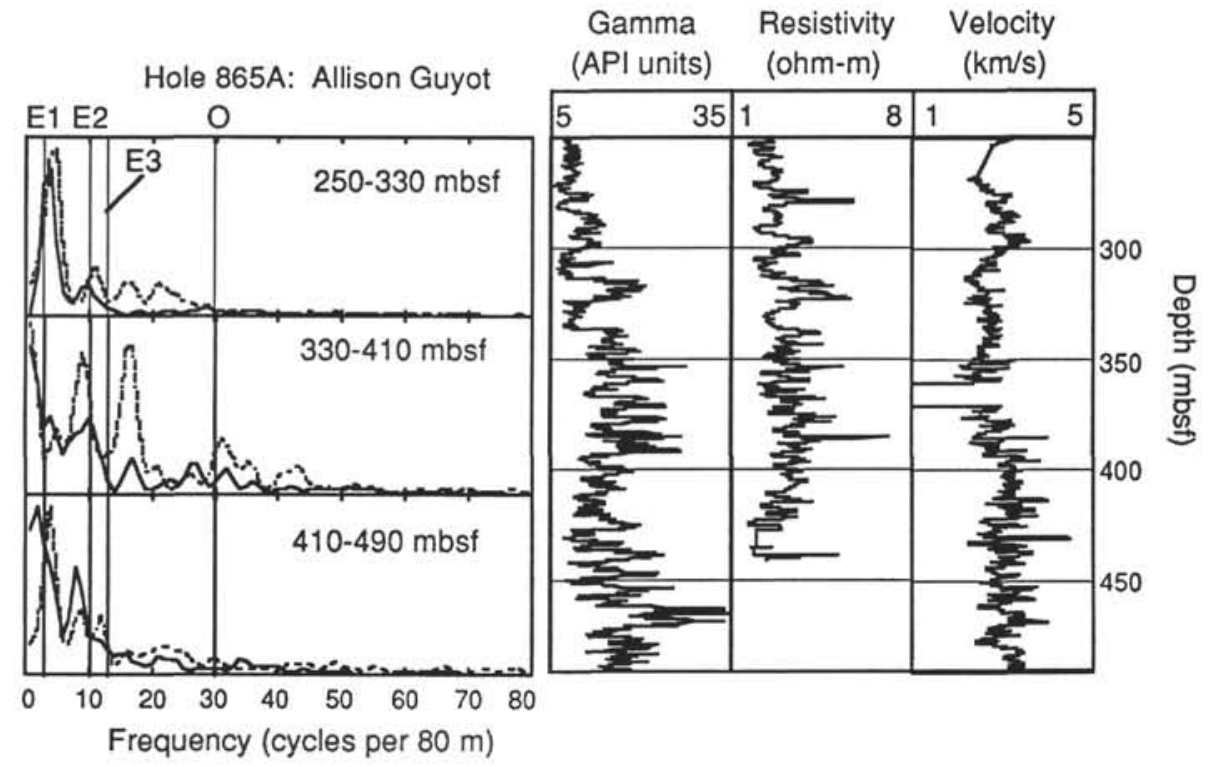

Figure 5. Gamma-ray, resistivity, and sonic log amplitude spectra for the interval from 250 to $490 \mathrm{mbsf}$ are shown in three 80 -m intervals. The vertical scale of spectra is percentage of total variance. Solid curve = gamma-ray log; dotted line $=$ resistivity log in upper two panels, sonic log in bottom panel. Assuming an average sedimentation rate of $65 \mathrm{~m} / \mathrm{m} . \mathrm{y}$. , predicted locations of orbital periods E1 (413 k.y.), E2 (123 k.y.), E3 (95 k.y.), and O (41 k.y) are at 3.0,10.1, 13.0, and 30.0 cycles per $80 \mathrm{~m}$, respectively. The logs have been plotted to the right of the spectra at a vertical depth scale that corresponds to the summed lengths of the windows.

and resistivity (solid-line spectrum) spectra and logs show little correlation in this depth interval. The 125- and 93-k.y. cycles, which would be in this frequency range, therefore are not resolved.

The spectrum for the depth interval from 464 to 497 mbsf shows good correlation between the gamma-ray and resistivity logs, but the sedimentation rate clearly is much less than the $33 \mathrm{~m} / \mathrm{m}$.y. indicated by the solid vertical lines. A dramatic change in sedimentation rate or period of nondeposition is probably the cause of the change in character of the spectra from depths greater than $531 \mathrm{mbsf}$, perhaps related to the Albian/Aptian boundary at $500 \mathrm{mbsf}$ (112 Ma; Shipboard Scientific Party, 1993c). Below this level, the gamma-ray and resistivity spectra show similar gross frequency contents. The peaks are located near the predicted Milankovitch frequencies and correlate well between depth intervals. The sedimentation rate is lowest in the interval from 497 to $531 \mathrm{mbsf}$ and increases downhole to $33 \mathrm{~m} / \mathrm{m}$.y. through the interval 631 to $664 \mathrm{mbsf}$.

\section{Lower Portion of Hole 866A}

Sedimentation rates continue to increase downhole to about 80 $\mathrm{m} / \mathrm{m} . \mathrm{y}$ in the lower section of Hole $866 \mathrm{~A}$. Gamma-ray and resistivity spectra for the lower portion of Hole 866A, 935-1165 mbsf (124.5-127.5 $\mathrm{Ma}$ ) correlate reasonably well. Usually the gamma-ray log anticorrelates with the resistivity log. However, sometimes the converse is true (Fig. 9), reflecting a close association of the biogenic carbon content with high porosity. The 413-k.y. eccentricity peak either is absent or has very low power in the resistivity spectra, but is present in the gamma-ray spectra; its amplitude increases downhole. The dominant 125-k.y. eccentricity peak reaches maximum amplitude in the interval from 1012 to 1165 mbsf. The 41-k.y. peak is broad, but clearly present in all three intervals.

\section{Tuning the Sedimentation Rate at Hole 866A}

The apparent sedimentation rate estimated from the spatial wavelength of the spectral peaks depends on the amplitude variance of the logs. Assuming correct identification of the Milankovitch periodicities, it should be possible to refine the sedimentation rates using the spatial wavelengths of the spectral peaks. A 40-m sliding window was passed down the resistivity $\log$ from 950 to $1200 \mathrm{mbsf}$, and spectra were calculated at $10-\mathrm{m}$ intervals. The locations of the $95-$ to $123-\mathrm{k} . \mathrm{y}$. spectral peaks with respect to upper and lower bounds on the sedimentation rate are shown in Figure 10. Each point is plotted at the window center depth (i.e., the spectrum calculated at $950 \mathrm{mbsf}$ contains data from $20 \mathrm{~m}$ above and below that depth). Sedimentation rate is seen to vary between 75 and $83 \mathrm{~m} / \mathrm{m}$.y. over the depth interval from 950 to 1140 mbsf, with a major excursion to a much lower sedimentation rate at $1060 \mathrm{mbsf}$. Minor grainstones recovered over the depth range of 1050 to 1070 mbsf may represent a short-lived highstand stage. The spectral peak is difficult to identify at depths greater than 1130 mbsf; from 1135 to 1165 mbsf (Cores $143-866 \mathrm{~A}-121 \mathrm{R}$ to $-124 \mathrm{R}$ ) laminated limonite mudstone and desiccation cracks provide evidence of numerous episodes of local emergence.

\section{DISCUSSION}

The chronology was not at all well constrained for Hole $865 \mathrm{~A}$; however, the evidence, both from rhythmic variations in sedimentation and spectral analysis of geophysical logs, still is compelling enough to imply that orbital forcing may be involved. Age control at Hole $866 \mathrm{~A}$ was sufficient to demonstrate with a good degree of confidence that the time scales of the rhythmic sedimentation have Milankovitch periods. Several questions arise: what is the mechanism or origin of the cycles, how are forced climate changes translated into lithologies, and what is the significance of the sedimentary cycles of various thicknesses, great and small?

Evidence of subaerial exposure strongly indicates sea-level oscillations of either eustatic or tectonic origin or some combination of the two as the mechanism for these Cretaceous platform cycles (Fischer, 1964; Grotzinger, 1986; Hardie et al., 1986; Strasser, 1991). Deposition of carbonates in a platform environment is primarily a function of space. The sedimentation rate is highly dependent on eustatic sea level and the rate of tectonic subsidence. Variation in productivity may be a small factor, but is probably not an important cause of the observed cyclicity.

In the lower part $(>600 \mathrm{~m}$ ) of Hole $866 \mathrm{~A}$ weathering of the volcanic edifice was the main source of clay for the surrounding lagoons (Shipboard Scientific Party, 1993c). At Site 865 and in the upper portion $(<600 \mathrm{~m})$ of Hole $866 \mathrm{~A}$, neighboring volcanoes may have provided the small clay fraction. Variations in clay supply may have been climatically controlled and a quiet, shallow lagoonal environment 
MILANKOVITCH CYCLES FROM FOURIER ANALYSIS

Site 866: Resolution Guyot

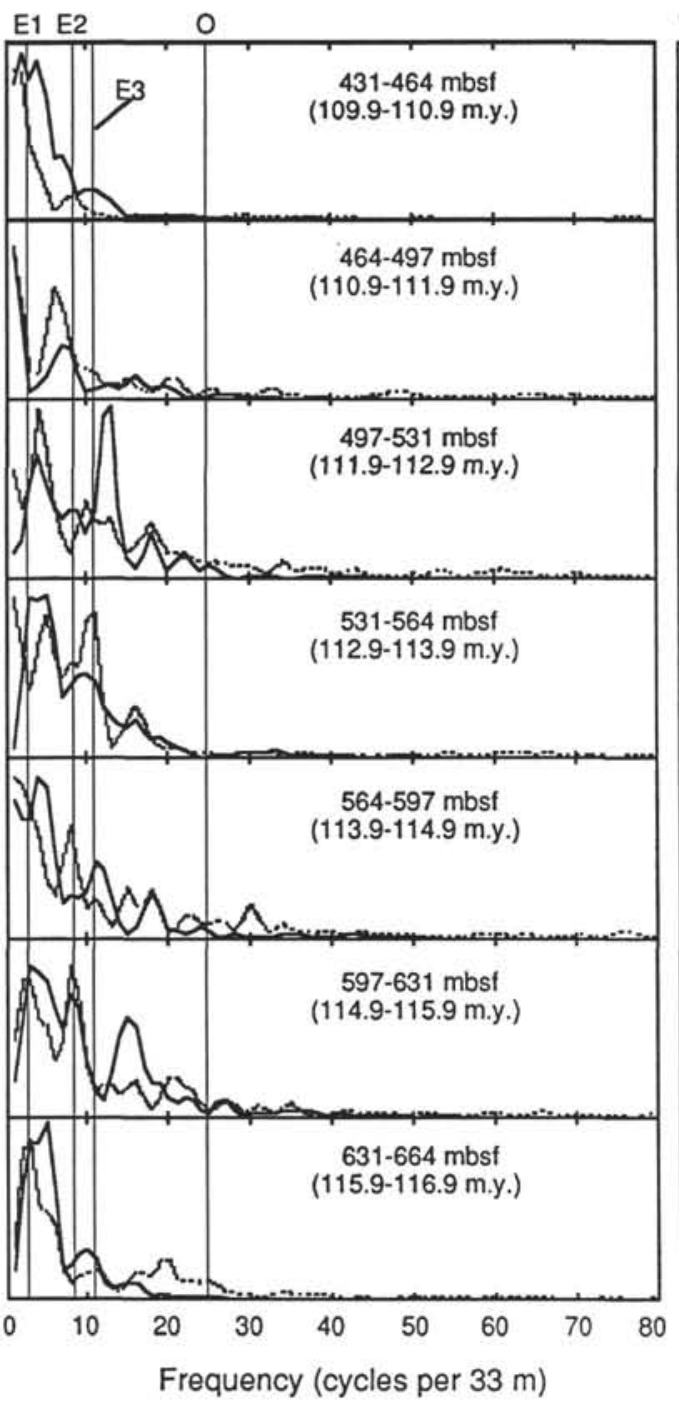

Log of Gamma-ray

resistivity (API units)

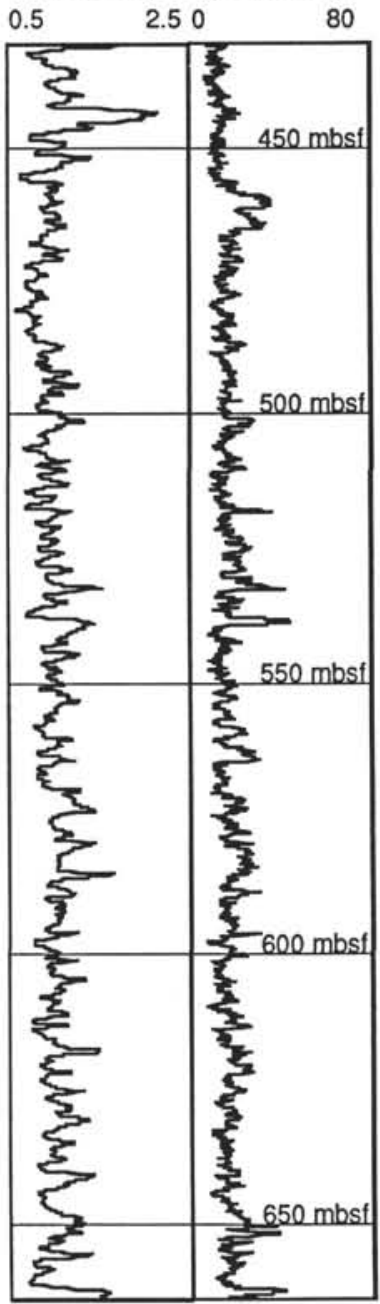

Figure 6. Gamma-ray and resistivity spectra for the interval from 431 to $664 \mathrm{mbsf}(109.9-116.9 \mathrm{Ma})$, shown in 33-m (1-m.y.) intervals. Vertical scale of spectra is percentage of total variance. Solid line $=$ resistivity log; dotted line $=$ gamma-ray $\log$. Assuming an average sedimentation rate of $33 \mathrm{~m} / \mathrm{m} . y$. , predicted locations of orbital periods E1 (413 k.y.), E2 (123 k.y.), E3 (95 k.y.), and O (41 k.y) are at 2.4, 8.0, 10.5, and 24.4 cycles per $33 \mathrm{~m}$, respectively. The corresponding segments of the resistivity and gamma-ray logs have been plotted to the right of the spectra at a vertical depth scale that corresponds to the summed lengths of the windows.

would have encouraged the near-source deposition of the clays derived from weathering of the volcanic edifice. With increasing water depth, circulation within the lagoonal environment is more energetic, removing the fine sediment fraction and concentrating the coarse-grained components. A probable cause of the cyclic fluctuations in resistivity (porosity) and gamma-ray values observed at these sites is increased deposition of clays and lime muds during lowstands, and winnowing or transport of fine-grained sediments during highstands.

The porosity-sensitive resistivity logs usually anticorrelate with the gamma-ray logs. Clay content increases downhole and, in general, increased clay content, indicated by elevated gamma-ray intensities, is associated with lower velocity and resistivity. Because porosity appears to be the main effect controlling the resistivity and sonic log responses, a likely explanation of these cycles is that they reflect climatic controls on sea level that, in turn, control clay supply and sorting.

Deposition in shallow lagoons is affected by (1) storms, (2) changes in current patterns and tidal channels and (3) short-term eustatic and tectonic sea-level fluctuations. Small, multimeter-scale, shallowing-upward cycles are especially well developed in the platform interior, lagoonal-peritidal settings, where typical cycles consist of mudstone that grades up to grainstone or packstone/wackestone. Boundaries of small cycles from Hole 866A are commonly marked by calcified algal mats, bird's eye vugs, and desiccation features indi- cating repeated exposure to subaerial diagenesis. Integration of core, FMS, and conventional logging data (Cooper et al., this volume) indicate thicknesses for these shallowing-upward cycles that range from 0.8 to $28.4 \mathrm{~m}$ at Hole 865 and 0.3 to $11.2 \mathrm{~m}$ at Hole $866 \mathrm{~A}$ (upper portion). Not all cycles are complete; migrating tidal channels, currents, and storms inevitably erode the surface of previously deposited sediments. Core materials recovered from nearby Sites 867/868 show evidence of storm deposition.

Mean thicknesses of 5.6 and $3.4 \mathrm{~m}$ were determined for the shallowing-upward sequences of Hole 865A and the upper portion of Hole 866A from an analysis of the FMS logs (Cooper et al., this volume). These thicknesses are comparable to the wavelengths of the 123- to 95-k.y. cycles for Hole 865A and upper portions of Hole $866 \mathrm{~A}, 7.9 / 6.2$ and $4.1 / 3.1 \mathrm{~m}$, respectively. The mean thickness of shallowing-upward sequences, as determined from the FMS log in the lower portion of Hole $866 \mathrm{~A}$ (Cooper et al., this volume), is $3.4 \mathrm{~m}$, comparable to the observed $3.2-\mathrm{m}$ spatial wavelength of the 41-k.y. obliquity cycle. This suggests that the 123-95-k.y. eccentricity cycle is represented by packets of rhythmic packstone-wackestone alternations, whereas the 41-k.y. obliquity cycle consists of some smaller portion of the packet.

Three possible reasons for the absence of the 41-k.y. signal in data from Hole $865 \mathrm{~A}$ and from the upper portion of Hole $866 \mathrm{~A}$ are (1) lack 
Figure 7. Gamma-ray and resistivity spectra for the interval from 935 to $1165 \mathrm{mbsf}$ (124.5-127.5 Ma), shown in 77-m (1-m.y.) intervals. Vertical scale of spectra is percentage of total variance. Solid line $=$ resistivity $\log$; dotted line $=$ gamma-ray log. Assuming an average sedimentation rate of $77 \mathrm{~m} / \mathrm{m} . y$. , predicted locations of orbital periods E1 (413 k.y.), E2 (123 k.y.), E3 (95 k.y.), and O (41 k.y) are at $2.4,8.0,10.5$, and 24.4 cycles per $77 \mathrm{~m}$, respectively. The corresponding segments of the resistivity and gamma-ray logs have been plotted to the right of the spectra at a vertical depth scale that corresponds to the summed lengths of the windows.

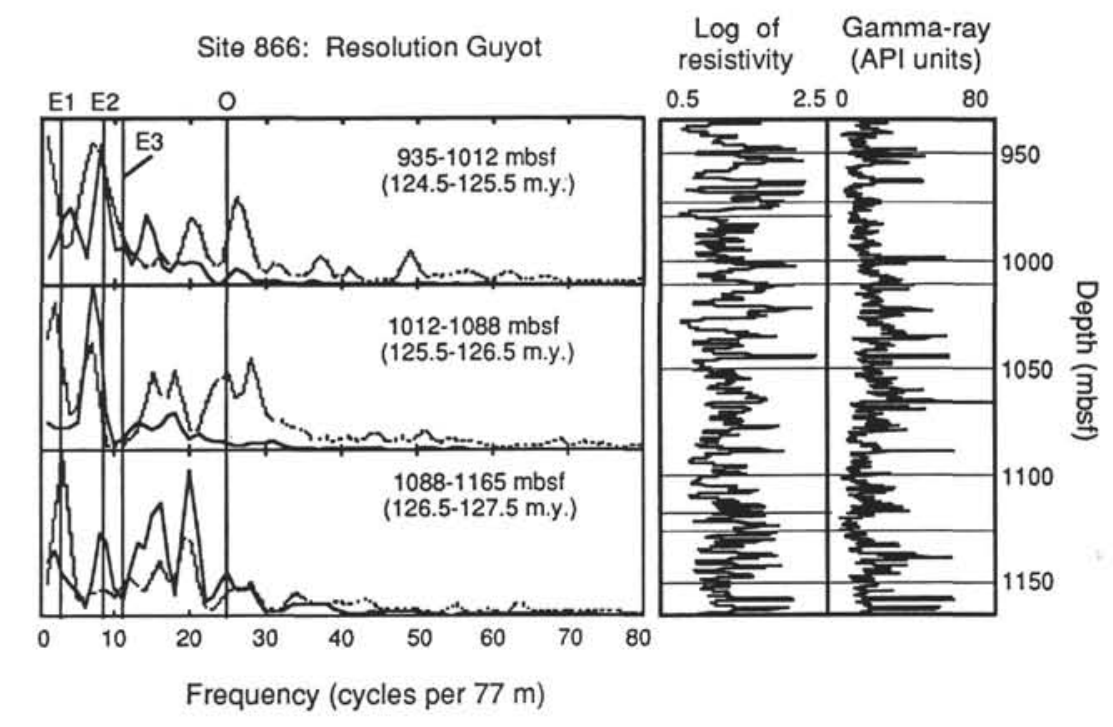

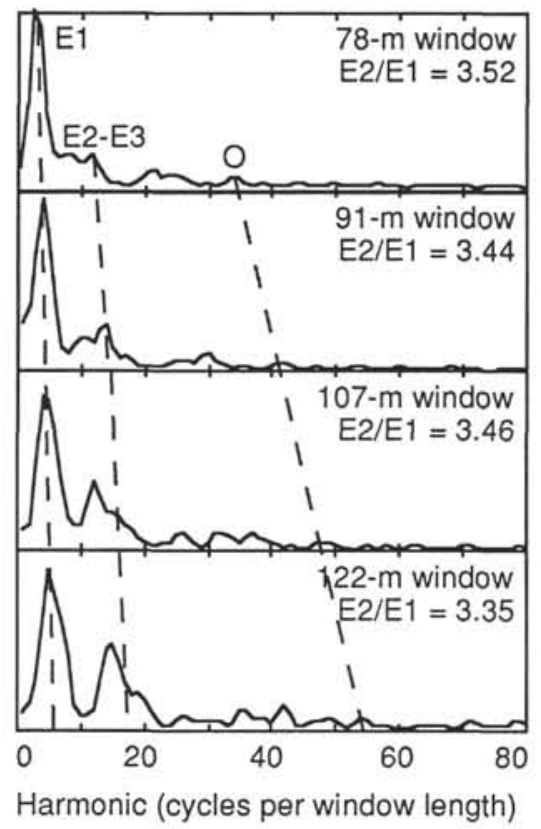

Figure 8. Spectral analyses of gamma-ray logs from Hole 865A. The size of the window for the Fourier transform was incremented to allow for confirmation of the locations of spectral peaks corresponding to Milankovitch periodicities. Ratios of E1 to E2 are shown.

of spatial resolution, (2) highly variable sedimentation rate, or (3) very low amplitude. Sedimentation rates at Hole $865 \mathrm{~A}(\sim 65 \mathrm{~m} / \mathrm{m} . \mathrm{y}$.) and in the lower portion of Hole $866 \mathrm{~A}(\sim 77 \mathrm{~m} / \mathrm{m} . \mathrm{y}$.) are high, so spatial resolution should be comparable at both sites. Deviations from the mean apparent sedimentation rate are also comparable at both sites. The major difference between the lower portion of Hole 866A and the upper portion of Holes $866 \mathrm{~A}$ and $865 \mathrm{~A}$ is the greater abundance of clay below $600 \mathrm{mbsf}$ in Hole 866A. This is speculative, but the additional clay and organic matter from the eroding Resolution volcanic edifice may amplify the obliquity signal in the gamma-ray $\log$. The distribution of clay seams and packets of clay seams throughout the core in the bottom portion of Hole 866A provides evidence of higher-frequency climatic fluctuations; however, the sedimentation rate is not high enough at this site to allow for resolution of spectral peaks shorter than the 41-k.y. cycle.

The small cycles are grouped into larger sequences that indicate a longer-term cyclic deepening and shallowing of the depositional environment (Arnaud et al., this volume). The distribution of $\mathrm{MnO}, \mathrm{Zn}$, and $\mathrm{Cu}$ (Röhl and Strasser, this volume) displays cycles on the order of 50 to $100 \mathrm{~m}$ in length in the lower portion of Hole $866 \mathrm{~A}$. Although these geochemical cycles are based on from four to six samples per interval, the trends are clear, and additional samples would not change the cycle lengths significantly. Peaks in the $\mathrm{MnO}$ content appear to be linked with facies deposited under the most restricted conditions and probably correspond to periods of maximum flooding (e.g., sequence boundaries 5, 7, 10, and 15 of Arnaud et al., this volume). The spatial wavelengths of these cycles are longer than the predicted wavelength for the 413-k.y. eccentricity cycles (31 m).

Cycles having periods much longer than $413 \mathrm{k} . \mathrm{y}$. are not resolved in the spectra because of the dominance of the 413-k.y. peak, the low-cut filtering effect of the windowing process, and standardization of the signal. Very long, irregularly spaced cycles of lowstand to highstand with distinctive diagenetic horizons are obvious in the core and logging data (Arnaud et al., this volume; Cooper et al., this volume), and, although their lengths are highly variable, they represent a likely explanation of the geochemical cycles observed by Röhl and Strasser (this volume).

A good deal of variation in the thickness of cycles exists between Site 865 and the Albian-age portion of Site 866 , so there remains the possibility that nonperiodic processes influenced cycle development at both the local and regional scales. Spectral maxima that are not near the predicted locations of peaks may have a nonorbital source for the cyclicity or may reflect a change in sedimentation rate. Most likely, occasional collapse of sections of beach mound or fringing reef that normally protect the lagoon from wave energy can expose the lagoon to open-ocean conditions. The cycling of such events is not entirely random, because they involve lateral transport and build-up of carbonate debris, slope destabilization, and collapse.

Variations in tectonic subsidence rate probably represent a major nonperiodic contribution to cycle development. Rapid sediment accumulation rates of about $80 \mathrm{~m} / \mathrm{m}$.y. during the Barremian slowed to about $30 \mathrm{~m} / \mathrm{m}$.y. during the Albian/Aptian at Resolution Guyot (Site 

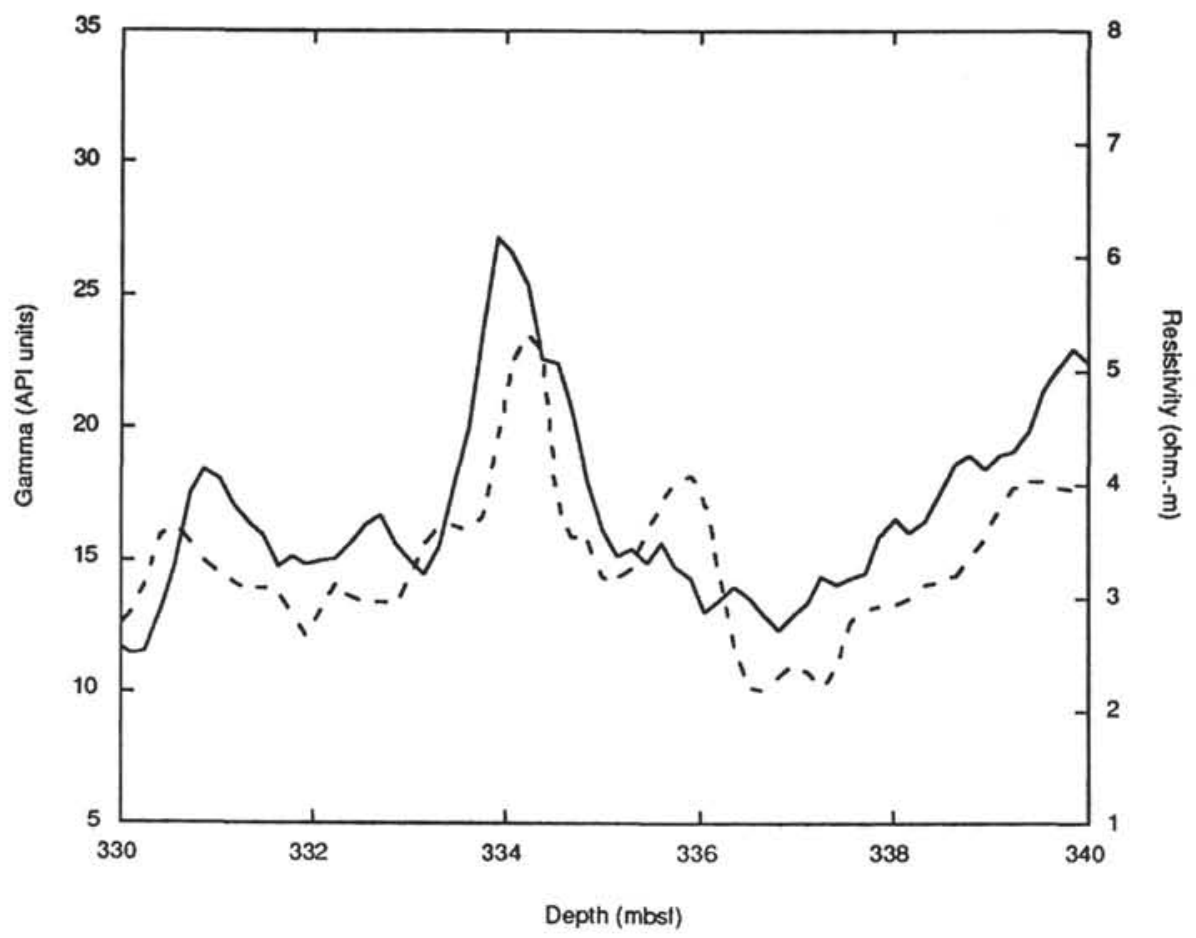

Figure 9. Expanded plot of the resistivity log and the gamma-ray log for a portion of Hole 866A, illustrating the close correlation between the two logs. Note resistivity log scale is logarithmic.

Hole 866A: 125 k.y. frequency

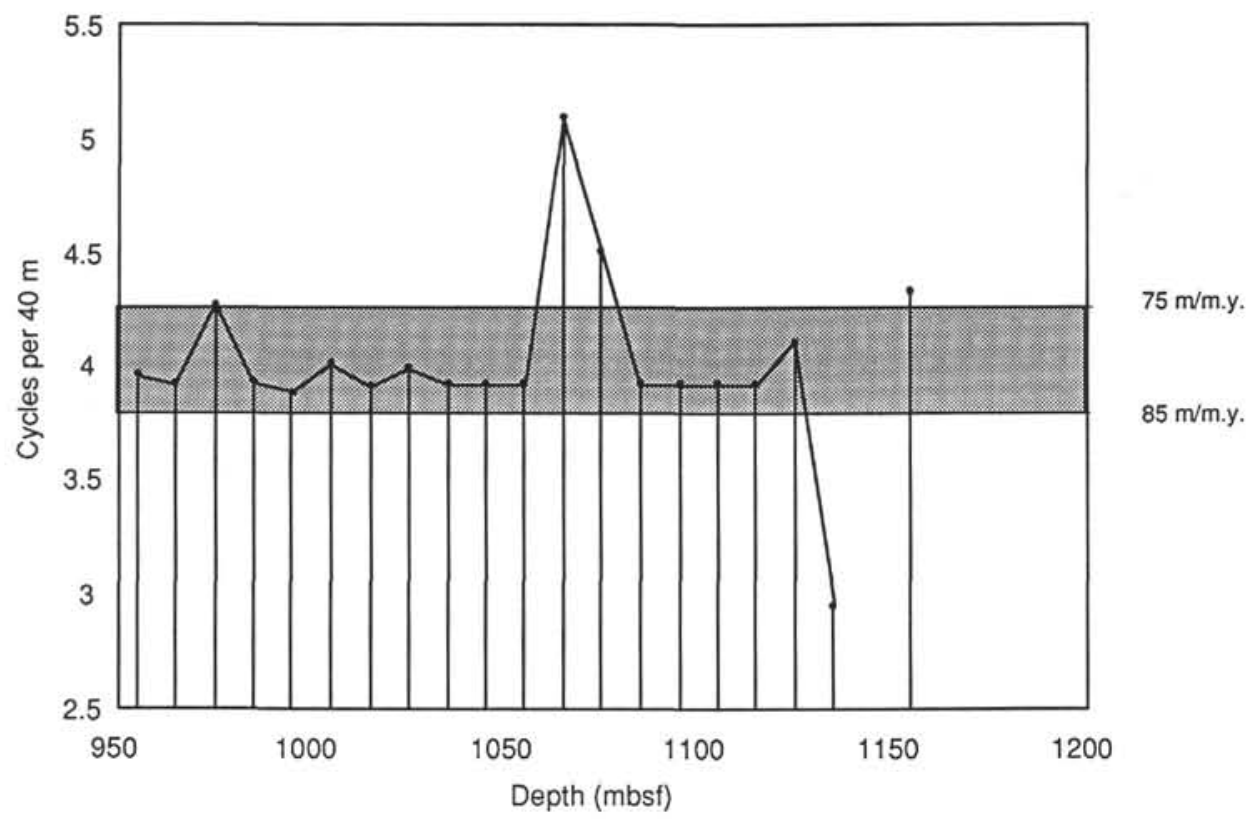

Figure 10. Plot of spatial frequency of 123-k.y. spectral peaks vs. depth for a 40-m sliding window. The data window for Fourier analysis was centered first on $950 \mathrm{mbsf}$ and moved downward in increments of $10 \mathrm{~m}$. The shaded portion indicates a range in sedimentation rates of 75 to $87 \mathrm{~m} / \mathrm{m}$.y. that brackets most of the time/depth period covered by the calculations. Excursions to lower sedimentation rates are seen at 1060 to 1070 mbsf.

866). Accumulation rates at the much younger Allison Guyot (Site 865 ) were about $65 \mathrm{~m} / \mathrm{m} . \mathrm{y}$. during the Albian. We may infer from this (1) that regional differences in tectonic subsidence rates exist that depend on the age of the volcanic edifice and (2) that the local subsidence rate may not be uniform throughout the growth of an individual platform and may contain pulses of uplift as well. The relatively high-frequency Milankovitch climate signal thus is superimposed on a nonperiodic low-frequency tectonic signal. Because the carbonate platforms of the Mid-Pacific guyots are far removed from terrigenous influences, the Milankovitch cycling represents as "pure" a eustatic signal as can be had. Therefore, it may be possible to extract the tectonic signal given excellent biostratigraphic or radiometric age control. 


\section{CONCLUSIONS}

Geophysical logs in the Cretaceous lagoonal carbonate facies of Holes $865 \mathrm{~A}$ and $866 \mathrm{~A}$ show pronounced cyclic variations in porosity and clay content. Spectral analysis of the logs reveals dominant peaks having spatial wavelength ratios that match the ratios of Milankovitch eccentricity cycles.

Mean sedimentation rates calculated from reconnaissance spectral analysis of long (200-m) data windows range from $65 \mathrm{~m} / \mathrm{m}$.y. for Hole $865 \mathrm{~A}, 33 \mathrm{~m} / \mathrm{m}$.y. for the upper portion of Hole $866 \mathrm{~A}$, to $77 \mathrm{~m} / \mathrm{m}$.y. for the lower portion of Hole 866A. No sedimentation rates were estimated from shipboard stratigraphy, but these values are consistent with the notion that Allison Guyot (Site 865) was a younger volcanic edifice that subsided at roughly twice the rate of Resolution Guyot (Site 866) throughout the late Albian.

A sliding window spectral analysis of the lower portion of Hole $866 \mathrm{~A}$ reveals details of fluctuations in sedimentation rates from 75 to $83 \mathrm{~m} / \mathrm{m}$.y. over the depth interval from 950 to $1150 \mathrm{mbsf}$. A short episode of very low sedimentation rates from 1050 to $1070 \mathrm{mbsf}$ corresponds to a cored interval containing minor grainstones and is interpreted as a short-lived highstand stage.

For both Hole $865 \mathrm{~A}$ and the upper portion of Hole 866A, the average thickness of the mudstone-wackestone-packstone shallowing-upwards cycles, as measured from the FMS images, is approximately equal to the predicted wavelength of the 123- to 95-k.y. cycles. No similar match was found for the 413-k.y. cycles. The 41-k.y. obliquity signal has high amplitude only in the lower portion of Hole $866 \mathrm{~A}$, perhaps because of the higher clay influx.

The Milankovitch cycles are evident in the sediments as simultaneous variations in porosity and clay content. Comparison of the resistivity and gamma-ray spectra shows that all the dominant frequencies are common to the two logs. Clay content increases downhole and, in general, increased clay content, indicated by elevated gamma-ray intensities, is associated with low resistivity. Because porosity appears to be the main effect controlling the resistivity response, a likely explanation of these cycles is that they reflect climatic controls on sea level that, in turn, control clay content and sorting.

\section{ACKNOWLEDGMENTS}

I thank the Ocean Drilling Program for inviting my participation in Leg 143 and the U.S. Science Advisory Committee and the Joint Oceanographic Institutions for providing financial support. This paper benefitted from reviews and discussions from Hubert Arnaud, Peter Flood, Rich Jarrard, Larry Mayer, Ursula Röhl, Will Sager, Annie Vanneau, and Jerry Winterer. This is SOEST Contribution No. 3548.

\section{REFERENCES*}

Arthur, M.A., 1979. North Atlantic Cretaceous black shales: the record at Site 398 and a brief comparison with other occurrences. In Sibuet, J.C., and Ryan, W.B.F., et al., Init. Repts. DSDP, 47 (Pt. 2): Washington (U.S. Govt. Printing Office), 719-751.

Arthur, M.A., Dean, W.E., Bottjer, D., and Scholle, P.A., 1984. Rhythmic bedding in Mesozoic-Cenozoic pelagic carbonate sequences: the primary and diagenetic origin of Milankovitch-like cycles. In Berger, A., Imbrie, J., Hays, J., Kukla, G., and Saltzman, B. (Eds.), Milankovitch and Climate (Pt. 1): Dordrecht (D. Reidel), 191-222.

Arthur, M.A., and Fischer, A.G., 1977. Upper Cretaceous-Paleocene magnetic stratigraphy at Gubbio, Italy, 1: lithostratigraphy and sedimentology. Geol. Soc. Am. Bull., 88:367-389.

"Abbreviations for names of organizations and publications in ODP reference lists follow
the style given in Chemical Abstracts Service Source Index (published by American the style given in $C$
Chemical Society).
Barron, E.J., Arthur, M.A., and Kauffman, E.G., 1985. Cretaceous rhythmic bedding sequences: a plausible link between orbital variations and climate. Earth Planet. Sci. Lett., 72:327-340.

Barron, E.J., and Washington, W.M., 1985. Warm Cretaceous climates: high atmospheric $\mathrm{CO}_{2}$ as a plausible mechanism. In Sundquist, E.T., and Broecker, W.S. (Eds.), The Carbon Cycle and Atmospheric $\mathrm{CO}_{2}$ : Natural Variations Archean to Present. Geophys. Monogr., Am. Geophys. Union, 32:546-553.

Berger, A., Imbrie, J., Hays, J., Kukla, G., and Saltzman, B. (Eds.), 1984. Milankovitch and Climate (Pts. 1 and 2): Dordrecht (D. Reidel).

Berger, A.L., 1977. Power and limitations of energy balance climate model as applied to the astronomical theory of paleoclimates. Palaeogeogr., Palaeoclimatol., Palaeoecol., 21:227-235.

Bloemendal, J., and deMenocal, P., 1989. Evidence for a change in the periodicity of tropical climate cycles at $2.4 \mathrm{Myr}$ from whole-core magnetic susceptibility measurements. Nature, 342:897-900.

Bradley, W.H., 1929. The varves and climate of the Green River. Geol. Surv. Prof. Pap. U.S., 158-E:87-110.

Briskin, M., and Harrell, J., 1980. Time-series analysis of the Pleistocene deep-sea paleoclimatic record. Mar. Geol., 36:1-22.

Cotillon, P., and Rio, M., 1984. Cyclic sedimentation in the Cretaceous of Deep Sea Drilling Project Sites 535 and 540 (Gulf of Mexico), 534 (Central Atlantic) and in the Vocontian Basin (France). In Buffler, R.T., Schlager, W., et al., Init. Repts. DSDP, 77: Washington (U.S. Govt. Printing Office), 339-376.

Dean, W.E., Gardner, J.V., Jansa, L.F., Cepek, P.I., Siebold, E., 1977. Cyclic sedimentation along the continental margin of Northwest Africa. In Lancelot, Y., Siebold, E., et al., Init. Repts. DSDP, 41: Washington (U.S. Govt. Printing Office), 965-990.

de Graciansky, P.C., and Gillot, E., 1985. Sedimentologic study of midCretaceous carbonaceous limestones at Sites 549 and 550, northeast Atlantic. In de Graciansky, P.C., and Poag, C.W., et al., Init. Repts. DSDP, 80: Washington (U.S. Govt. Printing Office), 885-897.

deMenocal, P.B., Bristow, J.F., and Stein, R., 1992. Paleoclimatic applications of downhole logs: Pliocene-Pleistocene results from Hole 798B, Sea of Japan. In Pisciotto, K.A., Ingle, J.C., Jr., von Breymann, M.T., Barron, J., et al., Proc. ODP, Sci. Results, $127 / 128$ (Pt. 1): College Station, TX (Ocean Drilling Program), 393-406.

Fischer, A.G., 1964. The Lofer cyclothems of the alpine Triassic. Bull.-Kans. Geol. Surv., 169:107-149.

Fischer, A.G., Herbert, T., and Premoli Silva, I., 1985. Carbonate bedding cycles in Cretaceous pelagic and hemipelagic sediments. In Pratt, L.M., Kauffman, E.G., and Zelt, F.B. (Eds.), Fine-grained Deposits and Biofacies of the Cretaceous Western Interior Seaway: Evidence of Cyclic Sedimentary Processes. SEPM Guidebook, 9:1-10.

Glenn, C.R., Kroon, D., and Wei, W., 1993. Sedimentary rhythms and climatic forcing of Pleistocene-Holocene mixed carbonates/siliciclastic sediments off the Great Barrier Reef. In McKenzie, J.A., Davies, P.J., Palmer-Julson, A., et al., Proc. ODP, Sci. Results, 133: College Station, TX (Ocean Drilling Program), 189-202.

Golovchenko, X., O'Connell, S.B., and Jarrard, R., 1990. Sedimentary response to paleoclimate from downhole logs at Site 693, Antarctic continental margin. In Barker, P.F., Kennett, J.P., et al., Proc. ODP, Sci. Results, 113: College Station, TX (Ocean Drilling Program), 239-251.

Grotzinger, J.P., 1986. Upward shallowing platform cycles: a response to 2.2 billion years of low-amplitude, high-frequency (Milankovitch band) sea level oscillations. Paleoceanography, 1:403-416.

Hardie, L.A., Bosellini, A., and Goldhammer, R.K., 1986. Repeated subaerial exposure of subtidal carbonate platforms, Triassic, northern Italy: evidence for high frequency sea level oscillations on a $10^{4}$ year scale. Paleoceanography, 1:447-457.

Harland, W.B., Armstrong, R.L., Cox, A.V., Craig, L.E., Smith, A.G., and Smith, D.G., 1990. A Geologic Time Scale 1989: Cambridge (Cambridge Univ. Press).

Hays, J.D., Imbrie, J., and Shackleton, N.J., 1976. Variations in the Earth's orbit: pacemaker of the ice ages. Science, 194:1121-1132.

Herbert, T.D., and Fischer, A.G., 1986. Milankovitch climatic origin of midCretaceous black shale rhythms in central Italy. Nature, 321:739-743.

Herbert, T.D., Stallard, R.F., and Fischer, A.G., 1986. Anoxic events, productivity rhythms, and the orbital signature in a mid-Cretaceous deep-sea sequence from central Italy. Paleoceanography, 1:495-506.

Imbrie, J., Hays, J.D., Martinson, D.G., McIntyre, A., Mix, A.C., Morley, J.J., Pisias, N.G., Prell, W.L., and Shackleton, N.J., 1984. The orbital theory of Pleistocene climate: support from a revised chronology of the marine $\delta^{18} \mathrm{O}$ 
record. In Berger, A., Imbrie, J., Hays, J., Kukla, G., and Saltzman, B. (Eds.), Milankovitch and Climate (Pt.1): Dordrecht (D. Reidel), 269-305.

James, P.N., 1977. Shallowing-upward sequences in carbonates. Geosci. Can., 4:126-136.

Jarrard, R.D., and Arthur, M.A., 1989. Milankovitch paleoceanographic cycles in geophysical logs from ODP Leg 105, Labrador Sea and Baffin Bay. In Srivastava, S.P., Arthur, M.A., Clement, B., et al., Proc. ODP, Sci. Results, 105: College Station, TX (Ocean Drilling Program), 757-772.

Jenkins, G.M., and Watts, D.G., 1968. Spectral Analysis and Its Applications: San Francisco (Holden Day).

Kemper, E., 1987. Das Klima der Kreide-Zeit. Geol. Jahrb., A96:5-185.

Mayer, L.A., Jansen, E., Backman, J., and Takayama, T., 1993. Climatic cyclicity at Site 806: the GRAPE record. In Berger, W.H., Kroenke, L.W., Mayer, L.A., et al., Proc. ODP, Sci. Results, 130: College Station, TX (Ocean Drilling Program), 623-639.

McCave, I.N., 1979. Depositional features of organic-carbon-rich black and green mudstones at DSDP Sites 386 and 387, western North Atlantic. In Tucholke, B.E., Vogt, P.R., et al., Init. Repts. DSDP, 43: Washington (U.S. Govt. Printing Office), 411-416.

Milankovitch, M., 1941. Kanon der Erdbestrahlung und seine Anwendung auf das Eiszeitenproblem. Acad. Royale Serbe, Edition Spec., 133. Israel Program for Scientific Translation, Jerusalem (published for the U.S. Dept. of Commerce and Nat. Sci. Found., 1969).

Molinie, A.J., and Ogg, J.G., 1992. Milankovitch cycles in upper Jurassic and Lower Cretaceous radiolarites of the equatorial Pacific: spectral analysis and sedimentation rate curves. In Larson, R.L., Lancelot, Y., et al., Proc. ODP, Sci. Results, 129: College Station, TX (Ocean Drilling Program), 529-547.

Mwenifumbo, C.J., and Blangy, J.P., 1991. Short-term spectral analysis of downhole logging measurements from Site 704. In Ciesielski, P.F., Kristoffersen, Y., et al., Proc. ODP, Sci. Results, 114: College Station, TX (Ocean Drilling Program), 577-585.

Nobes, D.C., Bloomer, S.F., Mienert, J., and Westall, F., 1991. Milankovitch cycles and nonlinear response in the Quaternary record in the Atlantic sector of the Southern Oceans. In Ciesielski, P.F., Kristoffersen, Y., et al., Proc. ODP, Sci. Results, 114: College Station, TX (Ocean Drilling Program), 551-576.

Olsen, P.E., Remington, C.L., Cornet, B., and Thompson, K.S., 1978. Cyclic change in Late Triassic lacustrine communities. Science, 201:729-733.

Park, J., and Herbert, T.D., 1987. Hunting for paleoclimatic periodicities in a geologic time series with an uncertain time scale. J. Geophys. Res., 92:14027-14040.

Prell, W.L., and Kutzbach, J.E., 1987. Monsoon variability over the past 150,000 years. J. Geophys. Res., 92:8411-8425.
Ruddiman, W.F., and McIntyre, A., 1984. Ice-age thermal response and climatic role of the surface North Atlantic Ocean, $40^{\circ} \mathrm{N}$ to $63^{\circ} \mathrm{N}$. Geol. Soc. Am. Bull., 95:381-396.

Sager, W.W., Winterer, E.L., Firth, J.V., et al., 1993. Proc. ODP, Init. Repts., 143: College Station, TX (Ocean Drilling Program).

Sarnthein, M., Winn, K., Duplessy, J.-C., and Fontugne, M.R., 1988. Global variations of surface ocean productivity in low and mid latitudes: influence on $\mathrm{CO}_{2}$ reservoirs of the deep ocean and atmosphere during the last 21,000 years. Paleoceanography, 3:361-399.

Schickendanz, P.T., and Bowen, E.G., 1977. The computation of climatological power spectra. J. Appl. Meteorol., 16:359-367.

Schlumberger, 1987. Log Interpretation Principles/Applications: Houston (Schlumberger).

Schwarzacher, W., 1964. An application of statistical time series analysis to a limestone-shale sequence. J. Geol., 72:195-213.

Shinn, E.A., 1983. Tidal flat environment. In Scholle, P.A., Bebout, D.G., and Moore, C.H.(Eds.), Carbonate Depositional Environments. AAPG Mem., 33:171-210.

Shipboard Scientific Party, 1993a. Site 865. In Sager, W.W., Winterer, E.L., Firth, J.V., et al., Proc. ODP, Init. Repts., 143: College Station, TX (Ocean Drilling Program), 111-180.

, 1993b. Site 866. In Sager, W.W., Winterer, E.L., Firth, J.V., et al., Proc. ODP, Init. Repts., 143: College Station, TX (Ocean Drilling Program), 181-271.

Start, G.G., and Prell, W.L., 1984. Evidence for two Pleistocene climatic modes: data from DSDP Site 502. In Berger, A., and Nicolis, C. (Eds.), New Perspectives in Climatic Modeling: Amsterdam (Elsevier), Develop. Atmos. Sci., 16:3-22.

Strasser, A., 1991. Lagoonal-peritidal sequences in carbonate environments: autocyclic and allocyclic processes. In Einsele, G., Ricken, W., and Seilacher, A. (Eds.), Cycles and Events in Stratigraphy: Berlin (SpringerVerlag), 709-721.

Sundquist, E.T., and Broecker, W.S. (Eds.), 1985. The Carbon Cycle and Atmospheric $\mathrm{CO}_{2}$ : Natural Variations, Archean to Present. Geophys. Monogr., Am. Geophys. Union, 32.

van Houten, F.B., 1964. Cyclic lacustrine sedimentation, Upper Triassic Lockatong Formation, central New Jersey and adjacent Pennsylvania. Bull.-Kans. Geol. Surv., 169:497-531.

Date of initial receipt: 1 December 1993

Date of acceptance: 5 July 1994

Ms 143SR-236 